\title{
Chemical composition of lipophilic extractives from jute (Corchorus capsularis) fibers used for manufacturing of high-quality paper pulps
}

\author{
José C. del Río*, Gisela Marques, Isabel M. Rodríguez, Ana Gutiérrez \\ Instituto de Recursos Naturales y Agrobiología de Sevilla, CSIC, P.O. Box 1052, E-41080 Seville, Spain
}

\section{A R T I C L E I N F O}

\section{Article history:}

Received 6 February 2009

Received in revised form 14 April 2009

Accepted 16 April 2009

\section{Keywords:}

Jute

Corchorus capsularis

Nonwood

Lipids

Fatty acids

Waxes

Sterols

Triterpenoids

Isomultiflorenone

Bauerenone

\begin{abstract}
A B S T R A C T
The chemical composition of the lipophilic extractives from jute (Corchorus capsularis) fibers, which are used for high-quality paper pulp manufacturing, was thoroughly studied. The extractives content was low $(0.4 \%)$, and its composition was studied by gas chromatography-mass spectrometry. For a better characterization of the different homologous series and compounds present in minor amounts, the extract was also fractionated by solid-phase extraction. The most predominant lipophilic compounds present in jute fibers were high molecular weight ester waxes ( $24 \%$ of total extract), followed by free fatty acids (17\%), free fatty alcohols (17\%) and $\alpha$-hydroxyfatty acids (14\%). Additionally, significant amounts of alkanes (6\%), $\omega$-hydroxyfatty acids (6\%), sterols (6\%), steroid and triterpenoid ketones $(3 \%)$ and steryl glycosides (1\%) were also identified, together with minor amounts of mono- and diglycerides.
\end{abstract}

(c) 2009 Elsevier B.V. All rights reserved.

\section{Introduction}

Jute (Corchorus capsularis) is an herbaceous annual plant from the Tiliaceae family, mostly grown in Southeast Asian countries. Jute fibers are separated from the bast or outer region of the stem after retting of the whole plant and are mainly used for the manufacture of cordage, carpets, bagging and wrapping materials, with an annual production of 2.65 million tons. In addition, jute fibers are a good source of different grades of paper pulp (Akhtaruzzaman and Shafi, 1995; Jahan, 2001). With the increasing concern over forest destruction and the increasing demand of paper pulp, the importance of jute for this purpose may increase. There have been previous published studies describing the characteristics of jute fibers, including the content of their main organic fractions, particularly lignin and carbohydrates, and its behavior during pulping (Akhtaruzzaman and Shafi, 1995; Jahan, 2001; Jahan et al., 2007, 2008). However, in order to maximize the exploitation of this fiber for paper pulp production, a more complete understanding of its chemistry is required.

In the present study, we report the chemical composition of lipophilic compounds from jute fibers, which up to our knowledge,

\footnotetext{
* Corresponding author. Tel.: +34 95 4624711; fax: +34 954624002.

E-mail address: delrio@irnase.csic.es (J.C. del Río).
}

has not been addressed before. It is well known that the content and composition of lipophilic compounds present in raw materials cause significant environmental and technical problems in the manufacturing of paper pulp (Back and Allen, 2000). During pulping, lipids are released from the fibers forming colloidal pitch, which can deposit in either pulp or machinery causing production troubles and important economic losses (Hillis and Sumimoto, 1989; Back and Allen, 2000). In the manufacture of alkaline pulps, a large part of the lipids originally present in the raw material is removed during the cooking and bleaching stages. However, some chemical species survive these processes and are found as pulp extractives (Gutiérrez et al., 2001a; Gutiérrez and del Río, 2003a; Bergelin and Holmbom, 2003; Freire et al., 2005, 2006), suspended in process waters (Gutiérrez et al., 2001b) or forming the so-called pitch deposits in circuits, equipments and final product (del Río et al., 1998, 2000; Silvestre et al., 1999; Bergelin et al., 2005; Gutiérrez and del Río, 2005). Pitch deposition is a serious problem in the pulp and paper industry since it is responsible for reduced production levels, higher equipment maintenance costs, higher operating costs and an increased incidence of defects in the final products (Back and Allen, 2000). Moreover, such extractives might contribute to the toxicity of paper pulp effluents and products (Ali and Sreekrishnan, 2001; Christianson-Heiska et al., 2008).

In this paper, the composition of the lipophilic compounds was carried out by gas chromatography (GC) and gas 
chromatography-mass spectrometry (GC-MS) using short- and medium-length high-temperature capillary columns, respectively, with thin films, which enables the elution and analysis of intact high molecular weight lipids such as waxes or sterol glycosides (Gutiérrez et al., 1998). Additionally, and for a more detailed characterization of the different homologous series and other minor compounds, the extract was fractionated by a simple solid-phase extraction (SPE) method using aminopropylphase cartridges, as described previously (Gutiérrez et al., 1998).

\section{Materials and methods}

\subsection{Sample}

Jute (C. capsularis) fibers were supplied by CELESA pulp mill (Tortosa, Spain). Jute fibers were air-dried. The dried samples were milled using a knife mill (Janke and Kunkel, Analysenmühle), and successively extracted with acetone in a Soxhlet apparatus for $8 \mathrm{~h}$ and hot water $\left(3 \mathrm{~h}\right.$ at $\left.100^{\circ} \mathrm{C}\right)$. The acetone extracts were evaporated to dryness, and resuspended in chloroform for chromatographic analysis of the lipophilic fraction. Two replicates were used for each sample.

\subsection{Solid-phase extraction (SPE) fractionation}

The lipid extracts were fractionated by a SPE procedure using aminopropyl-phase cartridges $(500 \mathrm{mg}$ ) from Waters Division of Millipore (Mildford, MA, USA), as already described (Gutiérrez et al., 1998). Briefly, the dried chloroform extracts were taken up in a minimal volume $(<0.5 \mathrm{~mL})$ of hexane:chloroform ( $4: 1)$ and loaded into the cartridge column previously conditioned with hexane $(4 \mathrm{~mL})$. The cartridge was loaded and eluted by gravity. The column was first eluted with $8 \mathrm{~mL}$ of hexane and subsequently with $10 \mathrm{~mL}$ of chloroform and finally with $10 \mathrm{~mL}$ of diethyl ether:acetic acid (98:2). Each isolated fraction was dried under nitrogen and analyzed by GC and GC-MS.

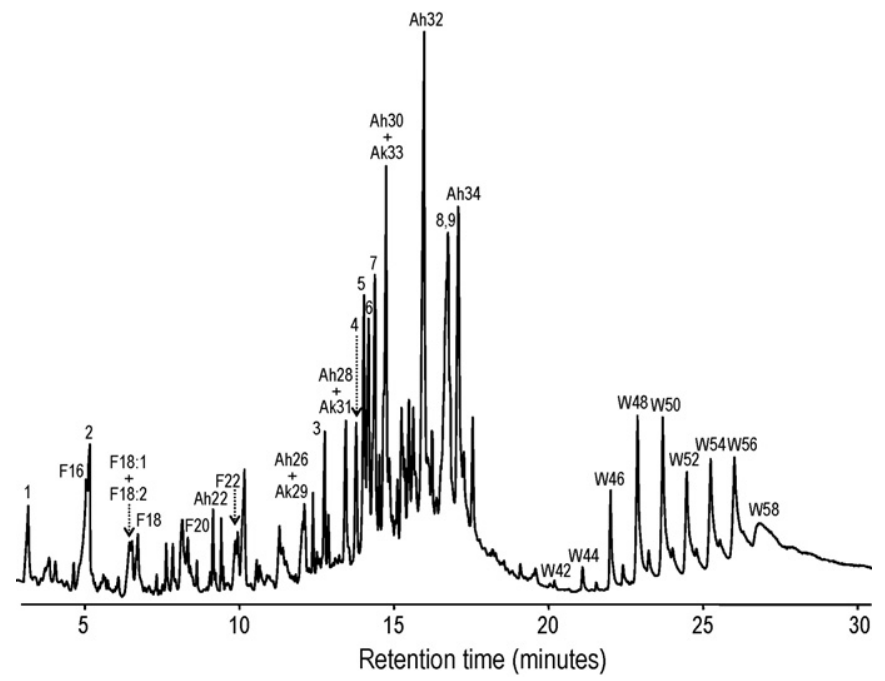

Fig. 1. GC-MS chromatogram of the underivatized lipid extracts from jute (C. capsularis) fibers. $\mathrm{F}(n): n$-fatty acid series; $\operatorname{Ak}(n)$ : $n$-alkane series; $\mathrm{Ah}(n): n$-fatty alcohol series; $\mathrm{W}(n)$ : high molecular weight ester wax series; $n$ denotes the total carbon atom number. Other compounds reflected are: (1) trans-coniferyl alcohol; (2) transsinapyl alcohol; (3) stigmasta-3,5,7-triene; (4) campesterol; (5) stigmasterol; (6) isomultiflorenone; (7) sitosterol; (8 and 9) unidentified triterpenoid compounds with epoxydammarane-type structure.

\subsection{GC and GC-MS analyses}

An HP 5890 gas chromatograph (Hewlett Packard, Hoofddorp, Netherlands) equipped with a split-splitless injector and a flame ionization detector (FID) was used for GC analyses. The injector and the detector temperatures were set at $300^{\circ} \mathrm{C}$ and $350^{\circ} \mathrm{C}$ respectively. Samples were injected in the splitless mode. Helium was used as the carrier gas. The capillary column used was a high-temperature, polyimide coated fused silica tubing DB5-HT ( $5 \mathrm{~m} \times 0.25 \mathrm{~mm}$ I.D., $0.1 \mu \mathrm{m}$ film thickness; J\&W Scientific). The oven was temperature-programmed from $100^{\circ} \mathrm{C}(1 \mathrm{~min})$ to $350^{\circ} \mathrm{C}$ ( $3 \mathrm{~min}$ ) at $15^{\circ} \mathrm{Cmin}^{-1}$. Peaks were quantified by area, and a mixture of standards (octadecane, palmitic acid, sitosterol, cholesteryl oleate, and sitosteryl $3 \beta$-D-glucopyranoside) was used to elaborate calibration curves. The data from the two replicates were averaged.

The GC-MS analysis were performed on a Varian Star 3400 gas chromatograph (Varian, Walnut Creek, CA) coupled with an iontrap detector (Varian Saturn) equipped with a high-temperature capillary column (DB-5HT, $15 \mathrm{~m} \times 0.25 \mathrm{~mm}$ i.d., $0.1 \mu \mathrm{m}$ film thickness; J\&W Scientific). Helium was used as carrier gas at a rate of $2 \mathrm{~mL} / \mathrm{min}$. The oven was heated from $120^{\circ} \mathrm{C}(1 \mathrm{~min})$ to
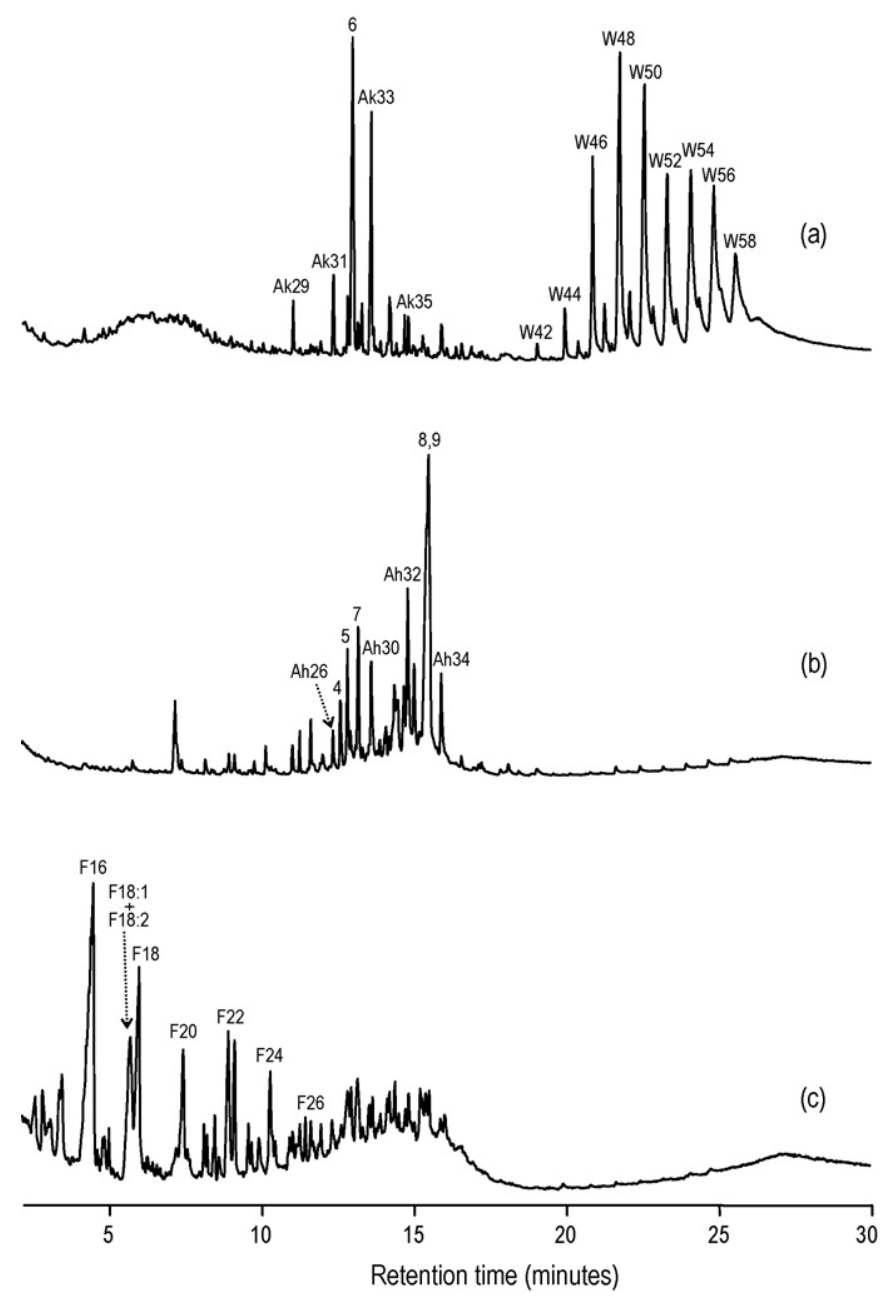

Fig. 2. GC-MS chromatograms of the different SPE fractions isolated from the extracts of jute fibers. (a) Fraction A, eluted with $8 \mathrm{~mL}$ of hexane; (b) fraction B, eluted with $10 \mathrm{~mL}$ of chloroform; and (c) fraction C, eluted with $10 \mathrm{~mL}$ diethyl ether:acetic acid (98:2). F(n): $n$-fatty acids series; $\mathrm{Ak}(n): n$-alkane series; $\mathrm{Ah}(n): n$-fatty alcohol series; $\mathrm{W}(n)$ : high molecular weight ester wax series; $n$ : denotes the total carbon atom number. Other compounds are: (4) campesterol; (5) stigmasterol; (6) isomultiflorenone; (7) sitosterol; (8 and 9) unidentified triterpenoid compounds with epoxydammarane-type structure. 
Table 1

Composition of lipids ( $\mathrm{mg} / \mathrm{kg}$ ) from jute (C. capsularis) fibers.

\begin{tabular}{|c|c|c|c|c|}
\hline Compounds & Mass fragments & MW & Formula & Abundance \\
\hline n-Alkanes & & & & 48.5 \\
\hline n-Heptacosane & $\underline{57 / 71 / 85 / 380}$ & 380 & $\mathrm{C}_{27} \mathrm{H}_{56}$ & 1.4 \\
\hline n-Octacosane & $\overline{57} / 71 / 85 / 394$ & 394 & $\mathrm{C}_{28} \mathrm{H}_{58}$ & 1.0 \\
\hline$n$-Nonacosane & $57 / 71 / 85 / 408$ & 408 & $\mathrm{C}_{29} \mathrm{H}_{60}$ & 6.3 \\
\hline$n$-Triacontane & $\overline{57} / 71 / 85 / 422$ & 422 & $\mathrm{C}_{30} \mathrm{H}_{62}$ & 1.5 \\
\hline n-Hentriacontane & $\overline{57} / 71 / 85 / 436$ & 436 & $\mathrm{C}_{31} \mathrm{H}_{64}$ & 8.0 \\
\hline$n$-Dotriacontane & $57 / 71 / 85 / 450$ & 450 & $\mathrm{C}_{32} \mathrm{H}_{66}$ & 2.5 \\
\hline n-Tritriacontane & $\overline{57} / 71 / 85 / 464$ & 464 & $\mathrm{C}_{33} \mathrm{H}_{68}$ & 20.6 \\
\hline$n$-Tetratriacontane & $57 / 71 / 85 / 478$ & 478 & $\mathrm{C}_{34} \mathrm{H}_{70}$ & 1.8 \\
\hline n-Pentatriacontane & $\overline{57} / 71 / 85 / 492$ & 492 & $\mathrm{C}_{35} \mathrm{H}_{72}$ & 5.4 \\
\hline Fatty acids & & & & 130.2 \\
\hline n-Tetradecanoic acid & $60 / 73 / 129 / 228$ & 228 & $\mathrm{C}_{14} \mathrm{H}_{28} \mathrm{O}$ & 2.4 \\
\hline n-Pentadecanoic acid & $60 / \underline{73} / 129 / 242$ & 242 & $\mathrm{C}_{15} \mathrm{H}_{30} \mathrm{O}$ & 5.5 \\
\hline n-Hexadecanoic acid & $60 / \underline{73} / 129 / 256$ & 256 & $\mathrm{C}_{16} \mathrm{H}_{32} \mathrm{O}_{2}$ & 30.1 \\
\hline n-Heptadecanoic acid & $60 / \overline{73} / 129 / 270$ & 270 & $\mathrm{C}_{17} \mathrm{H}_{34} \mathrm{O}_{2}$ & 1.5 \\
\hline 9,12 -Octadecadienoic acid & $67 / 81 / 280$ & 280 & $\mathrm{C}_{18} \mathrm{H}_{32} \mathrm{O}_{2}$ & 1.1 \\
\hline 9-Octadecenoic acid & $\underline{55} / 69 / 264$ & 282 & $\mathrm{C}_{18} \mathrm{H}_{34} \mathrm{O}_{2}$ & 18.9 \\
\hline n-Octadecanoic acid & $\overline{60} / 73 / 129 / 284$ & 284 & $\mathrm{C}_{18} \mathrm{H}_{36} \mathrm{O}_{2}$ & 11.3 \\
\hline n-Nonadecanoic acid & $60 / \overline{73} / 129 / 298$ & 298 & $\mathrm{C}_{19} \mathrm{H}_{38} \mathrm{O}_{2}$ & 0.5 \\
\hline$n$-Eicosanoic acid & $60 / 73 / 129 / 312$ & 312 & $\mathrm{C}_{20} \mathrm{H}_{40} \mathrm{O}_{2}$ & 6.6 \\
\hline$n$-Heneicosanoic acid & $60 / 73 / 129 / 326$ & 326 & $\mathrm{C}_{21} \mathrm{H}_{42} \mathrm{O}_{2}$ & 2.6 \\
\hline$n$-Docosanoic acid & $60 / \overline{73} / 129 / 340$ & 340 & $\mathrm{C}_{22} \mathrm{H}_{44} \mathrm{O}_{2}$ & 9.8 \\
\hline$n$-Tricosanoic acid & $60 / \overline{73} / 129 / 354$ & 354 & $\mathrm{C}_{23} \mathrm{H}_{46} \mathrm{O}_{2}$ & 3.1 \\
\hline n-Tetracosanoic acid & $60 / 73 / 129 / 368$ & 368 & $\mathrm{C}_{24} \mathrm{H}_{48} \mathrm{O}_{2}$ & 5.0 \\
\hline n-Pentacosanoic acid & $60 / \underline{73} / 129 / 382$ & 382 & $\mathrm{C}_{25} \mathrm{H}_{50} \mathrm{O}_{2}$ & 3.9 \\
\hline n-Hexacosanoic acid & $60 / \underline{73} / 129 / 396$ & 396 & $\mathrm{C}_{26} \mathrm{H}_{52} \mathrm{O}_{2}$ & 2.5 \\
\hline n-Heptacosanoic acid & $60 / \overline{73} / 129 / 410$ & 410 & $\mathrm{C}_{27} \mathrm{H}_{54} \mathrm{O}_{2}$ & 1.0 \\
\hline n-Octacosanoic acid & $60 / 73 / 129 / 424$ & 424 & $\mathrm{C}_{28} \mathrm{H}_{56} \mathrm{O}_{2}$ & 2.3 \\
\hline n-Nonacosanoic acid & $60 / \underline{73} / 129 / 438$ & 438 & $\mathrm{C}_{29} \mathrm{H}_{58} \mathrm{O}_{2}$ & 1.1 \\
\hline$n$-Triacontanoic acid & $60 / \underline{73} / 129 / 452$ & 452 & $\mathrm{C}_{30} \mathrm{H}_{60} \mathrm{O}_{2}$ & 6.5 \\
\hline$n$-Hentriacontanoic acid & $60 / 73 / 129 / 466$ & 466 & $\mathrm{C}_{31} \mathrm{H}_{62} \mathrm{O}_{2}$ & 1.1 \\
\hline$n$-Dotriacontanoic acid & $60 / 73 / 129 / 480$ & 480 & $\mathrm{C}_{32} \mathrm{H}_{64} \mathrm{O}_{2}$ & 7.9 \\
\hline$n$-Tritriacontanoic acid & $60 / \underline{73} / 129 / 494$ & 494 & $\mathrm{C}_{33} \mathrm{H}_{66} \mathrm{O}_{2}$ & 0.4 \\
\hline$n$-Tetratriacontanoic acid & $60 / \underline{73} / 129 / 508$ & 508 & $\mathrm{C}_{34} \mathrm{H}_{68} \mathrm{O}_{2}$ & 5.1 \\
\hline$\alpha$-Hydroxyfatty acids & & & & 102.8 \\
\hline 2-Hydroxytricosanoic acid & $73 / 397 / 441^{b}$ & $456^{\mathrm{b}}$ & $\mathrm{C}_{27} \mathrm{H}_{56} \mathrm{O}_{3} \mathrm{Si}^{\mathrm{b}}$ & 20.6 \\
\hline 2-Hydroxytetracosanoic acid & $73,411,455^{b}$ & $470^{\mathrm{b}}$ & $\mathrm{C}_{28} \mathrm{H}_{58} \mathrm{O}_{3} \mathrm{Si}^{\mathrm{b}}$ & 54.8 \\
\hline 2-Hydroxypentacosanoic acid & $73, \underline{425}, 469^{b}$ & $484^{\mathrm{b}}$ & $\mathrm{C}_{29} \mathrm{H}_{60} \mathrm{O}_{3} \mathrm{Si}^{\mathrm{b}}$ & 27.4 \\
\hline$\omega$-Hydroxyfatty acids & & & & 34.5 \\
\hline 22-Hydroxydocosanoic acid & $73,395,411, \underline{427}^{\mathrm{b}}$ & $442^{\mathrm{b}}$ & $\mathrm{C}_{26} \mathrm{H}_{54} \mathrm{O}_{3} \mathrm{Si}^{\mathrm{b}}$ & 30.6 \\
\hline 24-Hydroxytetracosanoic acid & $73,423,439,455^{\mathrm{b}}$ & $470^{\mathrm{b}}$ & $\mathrm{C}_{28} \mathrm{H}_{58} \mathrm{O}_{3} \mathrm{Si}^{\mathrm{b}}$ & 3.9 \\
\hline Fatty alcohols & & & & 127.0 \\
\hline$n$-Hexadecanol & $75 / 103 / 299^{a}$ & $314^{\mathrm{a}}$ & $\mathrm{C}_{19} \mathrm{H}_{42} \mathrm{OSi}^{\mathrm{a}}$ & 2.1 \\
\hline n-Octadecanol & $75 / 103 / \underline{327}^{\mathrm{a}}$ & $342^{\mathrm{a}}$ & $\mathrm{C}_{21} \mathrm{H}_{46} \mathrm{OSi}^{\mathrm{a}}$ & 2.4 \\
\hline$n$-Docosanol & $75 / 103 / \underline{383}^{a}$ & $398^{\mathrm{a}}$ & $\mathrm{C}_{25} \mathrm{H}_{54} \mathrm{OSi}^{\mathrm{a}}$ & 8.9 \\
\hline$n$-Tetracosanol & $75 / 103 / \underline{411}^{\mathrm{a}}$ & $426^{a}$ & $\mathrm{C}_{27} \mathrm{H}_{58} \mathrm{OSi}^{\mathrm{a}}$ & 2.1 \\
\hline$n$-Hexacosanol & $75 / 103 / 439^{a}$ & $454^{\mathrm{a}}$ & $\mathrm{C}_{29} \mathrm{H}_{62} \mathrm{OSi}^{\mathrm{a}}$ & 3.3 \\
\hline n-Octacosanol & $75 / 103 / \underline{467}^{a}$ & $482^{\mathrm{a}}$ & $\mathrm{C}_{31} \mathrm{H}_{66} \mathrm{OSi}^{\mathrm{a}}$ & 12.0 \\
\hline$n$-Triacontanol & $75 / 103 / 495^{\mathrm{a}}$ & $510^{\mathrm{a}}$ & $\mathrm{C}_{33} \mathrm{H}_{70} \mathrm{OSi}^{\mathrm{a}}$ & 24.2 \\
\hline$n$-Dotriacontanol & $75 / 103 / \overline{523}^{a}$ & $538^{a}$ & $\mathrm{C}_{35} \mathrm{H}_{74} \mathrm{OSi}^{\mathrm{a}}$ & 30.8 \\
\hline$n$-Tetratriacontanol & $75 / 103 / 551^{a}$ & $566^{a}$ & $\mathrm{C}_{37} \mathrm{H}_{78} \mathrm{OSi}^{\mathrm{a}}$ & 28.0 \\
\hline n-Hexatriacontanol & $75 / 103 / \overline{579}^{a}$ & $594^{\mathrm{a}}$ & $\mathrm{C}_{39} \mathrm{H}_{82} \mathrm{OSi}^{\mathrm{a}}$ & 6.2 \\
\hline n-Octatriacontanol & $75 / 103 / \underline{607}^{a}$ & $622^{\mathrm{a}}$ & $\mathrm{C}_{41} \mathrm{H}_{86} \mathrm{OSi}^{\mathrm{a}}$ & 6.2 \\
\hline$n$-Tetracontanol & $75 / 103 / \underline{635}^{a}$ & $650^{\mathrm{a}}$ & $\mathrm{C}_{43} \mathrm{H}_{90} \mathrm{OSi}^{\mathrm{a}}$ & 1.0 \\
\hline Steroid hydrocarbons & & & & 16.1 \\
\hline Ergosta-3,5,7-triene & $135 / 143 / 380$ & 380 & $\mathrm{C}_{28} \mathrm{H}_{44}$ & 0.9 \\
\hline Stigmastatetraene & $\overline{83 / 143 / 157 / 392}$ & 392 & $\mathrm{C}_{29} \mathrm{H}_{44}$ & 5.4 \\
\hline Stigmasta-3,5,7-triene & $\underline{135 / 143 / 394}$ & 394 & $\mathrm{C}_{29} \mathrm{H}_{46}$ & 6.0 \\
\hline Stigmasta-3,5-diene & $81 / 147 / 381 / \underline{396}$ & 396 & $\mathrm{C}_{29} \mathrm{H}_{48}$ & 3.7 \\
\hline Sterols & & & & 43.4 \\
\hline Campesterol & $55 / 145 / 213 / 382 / 400$ & 400 & $\mathrm{C}_{28} \mathrm{H}_{48} \mathrm{O}$ & 6.8 \\
\hline Stigmasterol & $\overline{55} / 83 / 255 / 394 / 412$ & 412 & $\mathrm{C}_{29} \mathrm{H}_{48} \mathrm{O}$ & 9.6 \\
\hline Sitosterol & $145 / 213 / 396 / 414$ & 414 & $\mathrm{C}_{29} \mathrm{H}_{50} \mathrm{O}$ & 20.7 \\
\hline Stigmastanol & $215 / 416$ & 416 & $\mathrm{C}_{29} \mathrm{H}_{52} \mathrm{O}$ & 1.0 \\
\hline 7-Oxo-campesterol & $\overline{135}, 161,381,414$ & 414 & $\mathrm{C}_{28} \mathrm{H}_{40} \mathrm{O}_{2}$ & 1.0 \\
\hline 7-Oxo-sitosterol & $135,161, \overline{395}, 428$ & 428 & $\mathrm{C}_{29} \mathrm{H}_{42} \mathrm{O}_{2}$ & 4.3 \\
\hline Epoxydammarane-type triterpenoids & & & & 64.8 \\
\hline Unknown compound peak 8 & $\underline{143} / 367$ & n.d. & n.d. & 51.7 \\
\hline Unknown compound peak 9 & $143 / 365$ & n.d. & n.d. & 13.1 \\
\hline
\end{tabular}


Table 1 (Continued)

\begin{tabular}{|c|c|c|c|c|}
\hline Compounds & Mass fragments & MW & Formula & Abundance \\
\hline Tocopherols & & & & 3.1 \\
\hline$\gamma$-Tocopherol & $\underline{151 / 191 / 416}$ & 416 & $\mathrm{C}_{28} \mathrm{H}_{48} \mathrm{O}_{2}$ & 1.0 \\
\hline$\alpha$-Tocopherol & $\overline{165} / 205 / 430$ & 430 & $\mathrm{C}_{29} \mathrm{H}_{50} \mathrm{O}_{2}$ & 2.1 \\
\hline Steroid/triterpenoid ketones & & & & 25.1 \\
\hline Stigmasta-3,5-dien-7-one & $174 / 269 / 410$ & 410 & $\mathrm{C}_{29} \mathrm{H}_{50} \mathrm{O}$ & 2.9 \\
\hline Stigmast-4-en-3-one & $\overline{124} / 229 / 412$ & 412 & $\mathrm{C}_{29} \mathrm{H}_{48} \mathrm{O}$ & 2.6 \\
\hline$\beta$-Amyrenone & $\overline{189} / 203 / 218 / 424$ & 424 & $\mathrm{C}_{30} \mathrm{H}_{48} \mathrm{O}$ & 1.0 \\
\hline Isomultiflorenone & $205 / 245 / 257 / 424$ & 424 & $\mathrm{C}_{30} \mathrm{H}_{48} \mathrm{O}$ & 17.6 \\
\hline Bauerenone & $\overline{205} / 245 / 257 / 424$ & 424 & $\mathrm{C}_{30} \mathrm{H}_{48} \mathrm{O}$ & 1.0 \\
\hline Steryl glycosides & & & & 8.4 \\
\hline Campesteryl 3 $\beta$-D-glucopyranoside & $204 / 217 / 361 / 383^{a}$ & $850^{\mathrm{a}}$ & $\mathrm{C}_{46} \mathrm{H}_{90} \mathrm{O}_{6} \mathrm{Si}_{4}{ }^{\mathrm{a}}$ & 1.0 \\
\hline 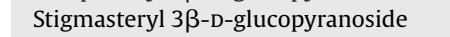 & $204 / 217 / 361 / 395^{a}$ & $862^{\mathrm{a}}$ & $\mathrm{C}_{47} \mathrm{H}_{90} \mathrm{O}_{6} \mathrm{Si}_{4}{ }^{\mathrm{a}}$ & 1.9 \\
\hline Sitosteryl $3 \beta$-D-glucopyranoside & $\overline{204} / 217 / 361 / 397^{a}$ & $864^{\mathrm{a}}$ & $\mathrm{C}_{47} \mathrm{H}_{92} \mathrm{O}_{6} \mathrm{Si}_{4}{ }^{\mathrm{a}}$ & 5.5 \\
\hline Waxes & & & & 181.2 \\
\hline Ester $\mathrm{C}_{42}$ & $\underline{57 / 257 / 313 / 620}$ & 620 & $\mathrm{C}_{42} \mathrm{H}_{84} \mathrm{O}_{2}$ & 0.7 \\
\hline Ester $\mathrm{C}_{44}$ & $\overline{57} / 257 / 285 / 341 / 648$ & 648 & $\mathrm{C}_{44} \mathrm{H}_{88} \mathrm{O}_{2}$ & 2.9 \\
\hline Ester $\mathrm{C}_{45}$ & $\underline{57} / 243 / 257 / 662$ & 662 & $\mathrm{C}_{45} \mathrm{H}_{90} \mathrm{O}_{2}$ & 1.1 \\
\hline Ester $\mathrm{C}_{46}$ & $\overline{57} / 257 / 285 / 676$ & 676 & $\mathrm{C}_{46} \mathrm{H}_{92} \mathrm{O}_{2}$ & 14.5 \\
\hline Ester $\mathrm{C}_{47}$ & $\overline{57} / 243 / 257 / 271 / 690$ & 690 & $\mathrm{C}_{47} \mathrm{H}_{94} \mathrm{O}_{2}$ & 3.1 \\
\hline Ester $\mathrm{C}_{48}$ & $\overline{57} / 257 / 285 / 704$ & 704 & $\mathrm{C}_{48} \mathrm{H}_{96} \mathrm{O}_{2}$ & 31.4 \\
\hline Ester $\mathrm{C}_{49}$ & $\overline{57} / 243 / 257 / 271 / 718$ & 718 & $\mathrm{C}_{49} \mathrm{H}_{98} \mathrm{O}_{2}$ & 3.4 \\
\hline Ester $C_{50}$ & $\overline{57} / 257 / 285 / 313 / 752$ & 732 & $\mathrm{C}_{50} \mathrm{H}_{100} \mathrm{O}_{2}$ & 30.2 \\
\hline Ester $C_{51}$ & $\underline{57} / 257 / 271 / 285 / 746$ & 746 & $\mathrm{C}_{51} \mathrm{H}_{102} \mathrm{O}_{2}$ & 2.0 \\
\hline Ester $\mathrm{C}_{52}$ & $\overline{57} / 257 / 285 / 313 / 760$ & 760 & $\mathrm{C}_{52} \mathrm{H}_{104} \mathrm{O}_{2}$ & 24.4 \\
\hline Ester $\mathrm{C}_{53}$ & $\underline{57} / 313 / 327 / 341 / 774$ & 774 & $\mathrm{C}_{53} \mathrm{H}_{106} \mathrm{O}_{2}$ & 1.7 \\
\hline Ester $\mathrm{C}_{54}$ & $\overline{57} / 313 / 341 / 368 / 788$ & 788 & $\mathrm{C}_{54} \mathrm{H}_{108} \mathrm{O}_{2}$ & 26.5 \\
\hline Ester $\mathrm{C}_{55}$ & $\overline{57} / 341 / 355 / 369 / 802$ & 802 & $\mathrm{C}_{55} \mathrm{H}_{110} \mathrm{O}_{2}$ & 1.6 \\
\hline Ester $\mathrm{C}_{56}$ & $\overline{57} / 341 / 369 / 397 / 816$ & 816 & $\mathrm{C}_{56} \mathrm{H}_{112} \mathrm{O}_{2}$ & 27.0 \\
\hline Ester $\mathrm{C}_{58}$ & $\underline{57} / 341 / 369 / 397844$ & 844 & $\mathrm{C}_{58} \mathrm{H}_{116} \mathrm{O}_{2}$ & 10.7 \\
\hline Monoglycerides & & & & 7.5 \\
\hline 2,3-Dihydroxypropylhexadecanoate & $73 / 147 / 203 / 371 / 459^{a}$ & $474^{\mathrm{a}}$ & $\mathrm{C}_{25} \mathrm{H}_{54} \mathrm{O}_{4} \mathrm{Si}^{\mathrm{a}}$ & 2.6 \\
\hline 2,3-Dihydroxypropyloctadec-9-enoate & $73 / 129 / 147 / 397 / 485^{a}$ & $500^{\mathrm{a}}$ & $\mathrm{C}_{23} \mathrm{H}_{56} \mathrm{O}_{4} \mathrm{Si}^{\mathrm{a}}$ & 1.9 \\
\hline 2,3-Dihydroxypropyloctadecanoate & $73 / 147 / 203 / 399 / 487^{a}$ & $502^{\mathrm{a}}$ & $\mathrm{C}_{27} \mathrm{H}_{58} \mathrm{O}_{4} \mathrm{Si}^{\mathrm{a}}$ & 1.9 \\
\hline 2,3-Dihydroxypropyltriacontanoate & $73 / 147 / 203 / 567 / 655^{\mathrm{a}}$ & $670^{\mathrm{a}}$ & $\mathrm{C}_{39} \mathrm{H}_{82} \mathrm{O}_{4} \mathrm{Si}^{\mathrm{a}}$ & 0.5 \\
\hline 2,3-Dihydroxypropyldotriacontanoate & $73 / 147 / 203 / \underline{595} / 683^{a}$ & $698^{\mathrm{a}}$ & $\mathrm{C}_{41} \mathrm{H}_{86} \mathrm{O}_{4} \mathrm{Si}^{\mathrm{a}}$ & 0.6 \\
\hline Diglycerides & & & & 13.5 \\
\hline 1,2-Dipalmitoylglycerol & $73 / 129 / 313 / 625^{a}$ & $640^{\mathrm{a}}$ & $\mathrm{C}_{38} \mathrm{H}_{76} \mathrm{O}_{5} \mathrm{Si}^{\mathrm{a}}$ & 1.0 \\
\hline 1,3-Dipalmitoylglycerol & $73 / 129 / 313 / 371 / 625^{a}$ & $640^{\mathrm{a}}$ & $\mathrm{C}_{38} \mathrm{H}_{76} \mathrm{O}_{5} \mathrm{Si}^{\mathrm{a}}$ & 3.7 \\
\hline 1,2-Oleoylpalmitoylglycerol & $73 / 129 / \underline{313} / 339 / 651^{a}$ & $666^{\mathrm{a}}$ & $\mathrm{C}_{40} \mathrm{H}_{78} \mathrm{O}_{5} \mathrm{Si}^{\mathrm{a}}$ & 1.2 \\
\hline 1,3-Oleoylpalmitoylglycerol & $73 / 129 / 339 / 371 / 651^{a}$ & $666^{\mathrm{a}}$ & $\mathrm{C}_{40} \mathrm{H}_{78} \mathrm{O}_{5} \mathrm{Si}^{\mathrm{a}}$ & 3.6 \\
\hline 1,2-Distearoylglycerol & $73 / 129 / 341 / \overline{681}^{\mathrm{a}}$ & $696^{a}$ & $\mathrm{C}_{42} \mathrm{H}_{84} \mathrm{O}_{5} \mathrm{Si}^{\mathrm{a}}$ & 1.4 \\
\hline 1,3-Distearoylglycerol & $73 / 129 / 341 / 399 / 681^{a}$ & $696^{\mathrm{a}}$ & $\mathrm{C}_{42} \mathrm{H}_{84} \mathrm{O}_{5} \mathrm{Si}^{\mathrm{a}}$ & 2.6 \\
\hline Total identified compounds & & & & 806.1 \\
\hline
\end{tabular}

a TMS ether.

b TMS ether, methyl ester.

$380^{\circ} \mathrm{C}(5 \mathrm{~min})$ at $10^{\circ} \mathrm{C} / \mathrm{min}$. The temperature of the injector during the injection was $120^{\circ} \mathrm{C}$, and $0.1 \mathrm{~min}$ after injection was programmed to $380^{\circ} \mathrm{C}$ at a rate of $200^{\circ} \mathrm{C} / \mathrm{min}$ and held for $10 \mathrm{~min}$. The temperature of the transfer line was set at $300^{\circ} \mathrm{C}$. Bis(trimethylsilyl)trifluoroacetamide (BSTFA) silylation were used where required. Compounds were identified by comparing their mass spectra with mass spectra in the Wiley and NIST libraries, by mass fragmentography and, when possible, by comparison with authentic standards.

\section{Results and discussion}

The total acetone extractives of jute fibers accounts for $0.4 \%$ of dry material. This content is similar to that found in other nonwood fibers (i.e. flax, hemp, kenaf, sisal, abaca or giant reed) commonly used for papermaking (Gutiérrez and del Río, 2003a; Gutiérrez et al., 2006, 2008; del Río and Gutiérrez, 2006; Coelho et al., 2007).

The underivatized and silylated lipophilic extracts from jute fibers were analyzed by GC and GC-MS using short- and mediumlength high-temperature capillary columns, respectively, with thin films, according to the method previously described (Gutiérrez et al., 1998). The GC-MS chromatogram of the underivatized lipid extracts from jute fibers is shown in Fig. 1. For a better characterization of the compounds present in the total extracts of jute fibers, the extracts were also subjected to a SPE fractionation according to the method developed by Gutiérrez et al. (1998). The chromatograms of the different SPE fractions are shown in Fig. 2. The first fraction (A), eluted with hexane, was enriched in hydrocarbons, ester waxes and triterpenoids and steroid ketones. The second fraction (B), eluted with chloroform, contained sterols, fatty alcohols and mono- and diglycerides. The final fraction (C), eluted with diethyl ether-acetic acid (98:2), was enriched in free fatty acids. The identities and abundances of the main lipophilic compounds identified among the jute lipophilic extractives are detailed in Table 1.

The most predominant lipophilic compounds present in jute fibers were series of high molecular weight ester waxes (24\% of total identified compounds), followed by series of free fatty acids (17\%), free fatty alcohols (17\%) and $\alpha$-hydroxyfatty acids (14\%). Additionally, lower amounts of other aliphatic series such as $n$-alkanes (6\%) and $\omega$-hydroxyfatty acids (6\%), were also found. Steroid and triterpenoid compounds were also present among jute lipophilic extracts, together with minor amounts of tocopherols as well as mono- and diglycerides. The structures of the main lipophilic compounds present in jute fibers are depicted in Fig. 3 and the 


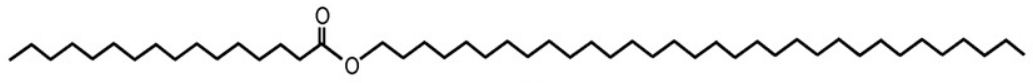

(I)

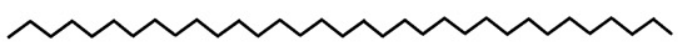

(II)<smiles>CCCCCCCCCCCCCC(=O)O</smiles>

(III)<smiles>CCCCCCCC=CCCCCCCC(=O)O</smiles>

(IV)<smiles>CCCCCCCCCCCCCCCCCCCC(O)C(O)O</smiles>

(V)

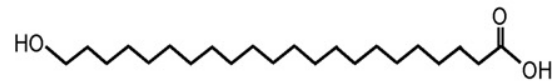

(VI)
(VII)<smiles>Cc1c(C)c2c(c(C)c1O)OC(CCCCCCC(C)CCCC(C)C)CC2</smiles>

(VIII)

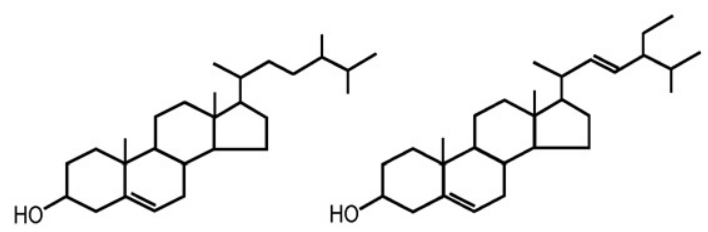

(IX)
(X)<smiles>CCC(C)CCC(C)C1CCC2C3CC4=CC(O)CCC4C3CCC12C</smiles>

(XI)

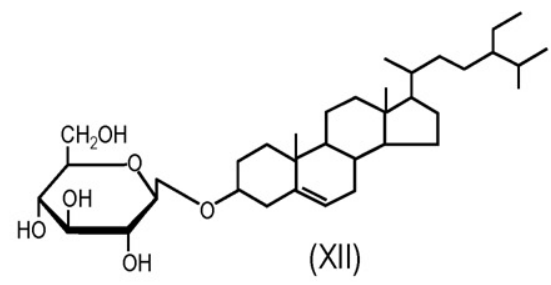<smiles>CCC(C)CCC(C)C1CCC2C3=CC4CC5CCCC4C5CCC3C2C1</smiles>

(XIII)<smiles>CCC(C)CCC1CCC2C1CCC1C3CCC=CC3=CC(=O)CC12C</smiles>

(XIV)<smiles>CCC(C)CCC(C)C1CCC2C3CCC4CC(=O)CCC4(CCC13)C2C</smiles>

(XV)

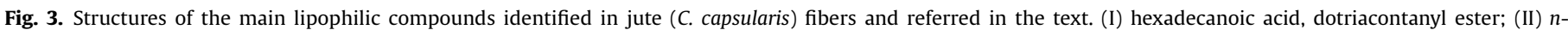

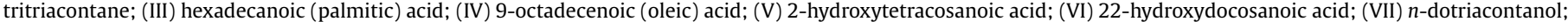

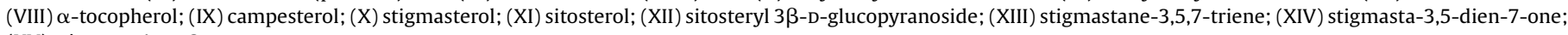
(XV) stigmast-4-en-3-one.

distributions of the main aliphatic series present in jute fibers are represented in the histograms of Fig. 4.

High molecular weight ester waxes (formed by long-chain fatty acids esterified to long-chain fatty alcohols) were found in a high abundance $(181.2 \mathrm{mg} / \mathrm{kg})$ among the jute extracts. High molecular weight ester waxes are also prominent among the extracts of other bast fibers, such as flax, hemp or kenaf (Gutiérrez and del Río, 2003a,b; Gutiérrez et al., 2006). They were present in the range from $\mathrm{C}_{42}$ to $\mathrm{C}_{58}$, with a strong even-over-odd carbon atom predominance and the $\mathrm{C}_{48}, \mathrm{C}_{50}, \mathrm{C}_{52}, \mathrm{C}_{54}$ and $\mathrm{C}_{56}$ homologues being the most abundant. Waxes with unsaturated fatty acids could not be detected, despite the relatively high amount of oleic acid being present in free form, as shown below. Each chromatographic ester peak consisted of a complex mixture of different long-chain fatty acids esterified to different long-chain fatty alcohols that coelute together in the same peak. The identification and quantitation of the individual long-chain esters present in each chromatographic peak was accomplished based on the mass spectra of the peaks. Fig. 5 shows the mass spectrum of the chromatographic peak corresponding to the long-chain ester wax $\mathrm{C}_{44}$. The mass spectra of long-chain esters are characterized by a base peak produced by a rearrangement process involving the transfer of $2 \mathrm{H}$ atoms from the alcohol chain to the acid chain giving a protonated acid ion (Sharkey et al., 1959; Moldovan et al., 2002). The fragments at $\mathrm{m} / \mathrm{z}$ 229, 257, 285, 313 and 341 of the mass spectra in Fig. 5 correspond therefore to protonated tetradecanoic, hexadecanoic, octadecanoic, eicosanoic and docosanoic acids, respectively. Therefore, this mass fragment gives information about the number of carbon atoms in 


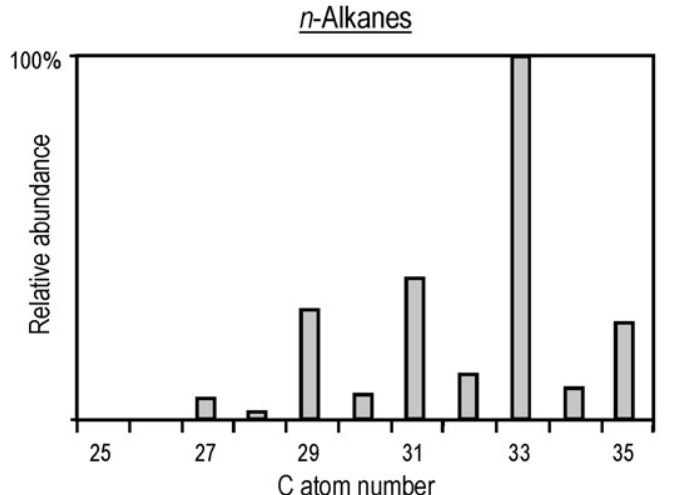

Free $n$-Fatty acids

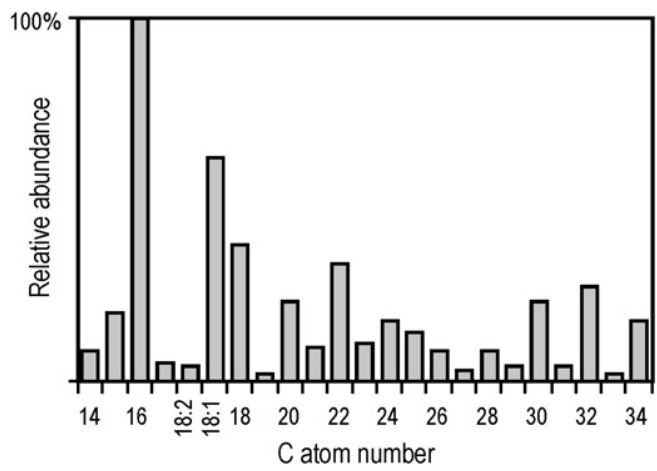

Esterified $n$-Fatty acids

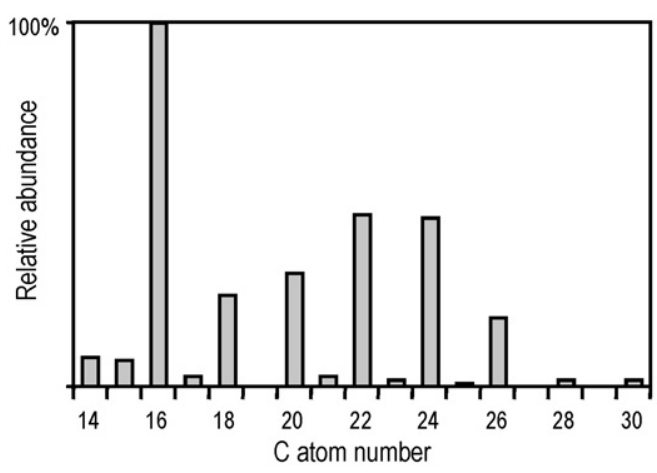

$\underline{\text { Waxes }}$

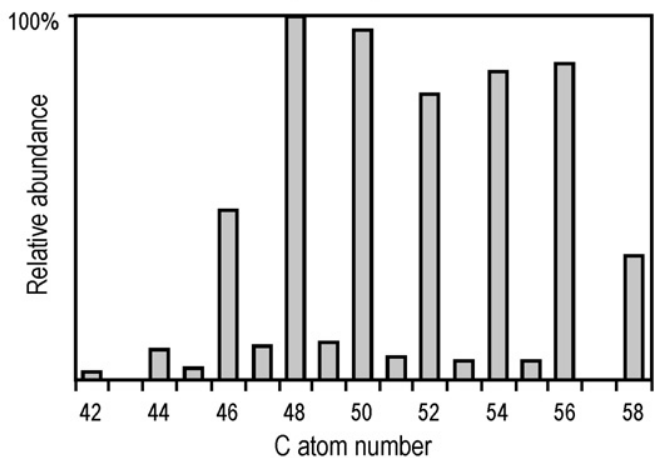

Free n-Fatty alcohols

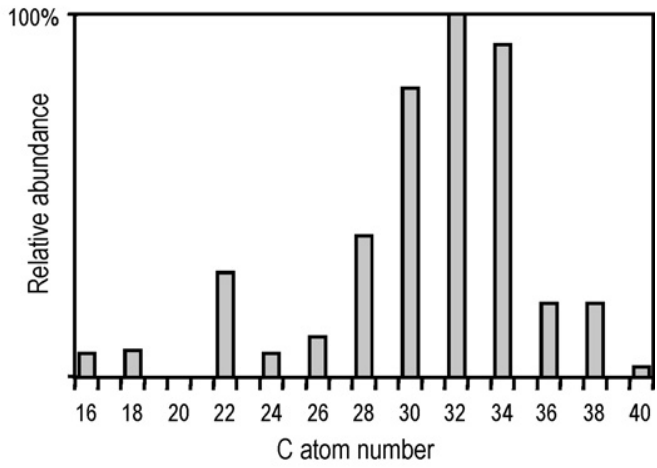

Esterified $n$-Fatty alcohols

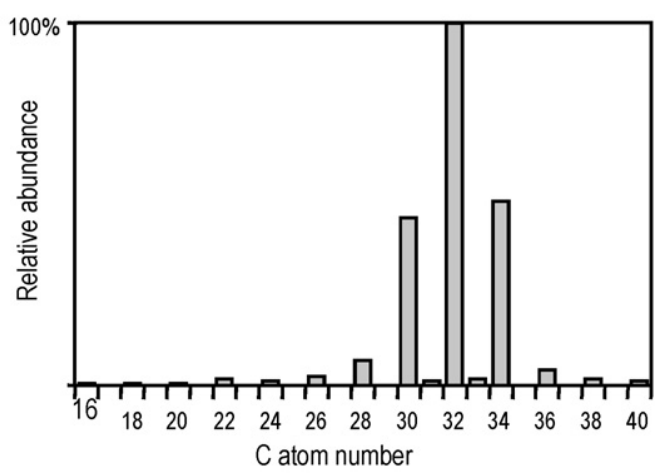

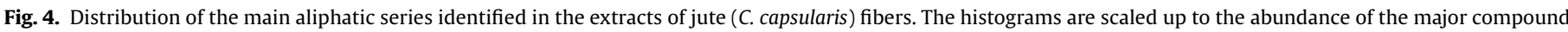
in the series.

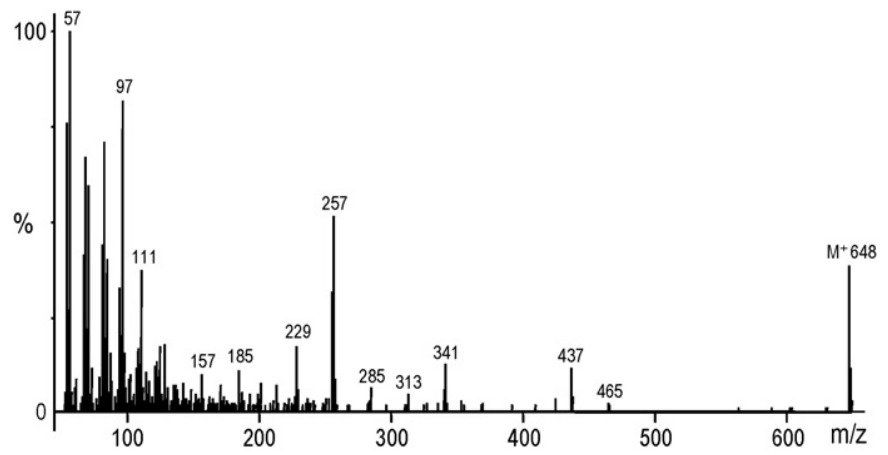

Fig. 5. Mass spectrum of the chromatographic peak corresponding to long-chain ester wax $\mathrm{C}_{44}$. The fragments at $m / z 229,257,285,313$ and 341 correspond to protonated tetradecanoic, hexadecanoic, octadecanoic, eicosanoic and docosanoic acids, respectively. the acid moiety whereas the molecular ion $\left(\mathrm{M}^{+} 648\right.$ in this particular case) gives information on the total number of carbon atoms in the ester (a $\mathrm{C}_{44}$ ester in this particular case), being then possible to determine the individual contribution of esters to every chromatographic peak by mass spectrometry. Quantitation of individual esters was accomplished by integration of the areas of the chromatographic profiles of the characteristic ions for the acidic moiety. A detailed structural characterization of the high molecular weight ester waxes present in the extracts of jute fibers is shown in Table 2 . The distribution of the series of esterified fatty acids and fatty alcohols is shown in Fig. 4. The esterified fatty acids ranged from $C_{14}$ to $C_{30}$ and the esterified fatty alcohols ranged from $C_{16}$ to $\mathrm{C}_{40}$. The acid moiety of the waxes was exclusively constituted by saturated fatty acids with a very strong predominance of the even carbon atom number homologues. Among these, the most predominant one was hexadecanoic $\left(\mathrm{C}_{16}\right)$ acid followed by docosanoic $\left(\mathrm{C}_{22}\right)$ and tetracosanoic $\left(\mathrm{C}_{24}\right)$ acids. Among the alcohol moiety of the high molecular weigh ester waxes, the most predominant was 
Table 2

Composition and abundance $(\mathrm{mg} / \mathrm{kg})$ of the individual high molecular weight ester waxes present in jute (C. capsularis) fiber extracts.

\begin{tabular}{|c|c|c|}
\hline Individual esters & $\begin{array}{l}\text { Fatty acid:fatty } \\
\text { alcohol }\end{array}$ & Abundance \\
\hline Ester $C_{42}$ & & 0.7 \\
\hline Hexadecanoic acid, hexacosyl ester & $\mathrm{C}_{16}: \mathrm{C}_{26}$ & 0.4 \\
\hline Octadecanoic acid, tetracosyl ester & $\mathrm{C}_{18}: \mathrm{C}_{24}$ & 0.1 \\
\hline Eicosanoic acid, docosyl ester & $\mathrm{C}_{20}: \mathrm{C}_{22}$ & 0.2 \\
\hline Ester $C_{44}$ & & 2.9 \\
\hline Tetradecanoic acid, triacontyl ester & $\mathrm{C}_{14}: \mathrm{C}_{30}$ & 0.5 \\
\hline Hexadecanoic acid, octacosyl ester & $\mathrm{C}_{16}: \mathrm{C}_{28}$ & 1.7 \\
\hline Octadecanoic acid, hexacosyl ester & $\mathrm{C}_{18}: \mathrm{C}_{26}$ & 0.2 \\
\hline Eicosanoic acid, tetracosyl ester & $\mathrm{C}_{20}: \mathrm{C}_{24}$ & 0.1 \\
\hline Docosanoic acid, docosyl ester & $\mathrm{C}_{22}: \mathrm{C}_{22}$ & 0.3 \\
\hline Tetracosanoic acid, heneicosyl ester & $\mathrm{C}_{24}: \mathrm{C}_{20}$ & 0.1 \\
\hline Ester $C_{45}$ & & 1.1 \\
\hline Tetradecanoic acid, hentriacontyl ester & $C_{14}: C_{31}$ & 0.1 \\
\hline Pentadecanoic acid, triacontyl ester & $C_{15}: C_{30}$ & 0.8 \\
\hline Hexadecanoic acid, nonacosyl ester & $C_{16}: C_{29}$ & 0.2 \\
\hline Ester $C_{46}$ & & 14.5 \\
\hline Tetradecanoic acid, dotriacontyl ester & $\mathrm{C}_{14}: \mathrm{C}_{32}$ & 1.7 \\
\hline Hexadecanoic acid, triacontyl ester & $\mathrm{C}_{16}: \mathrm{C}_{30}$ & 10.8 \\
\hline Octadecanoic acid, octacosyl ester & $\mathrm{C}_{18}: \mathrm{C}_{28}$ & 0.5 \\
\hline Eicosanoic acid, hexacosyl ester & $\mathrm{C}_{20}: \mathrm{C}_{26}$ & 0.2 \\
\hline Docosanoic acid, tetracosyl ester & $\mathrm{C}_{22}: \mathrm{C}_{24}$ & 0.2 \\
\hline Tetracosanoic acid, docosyl ester & $\mathrm{C}_{24}: \mathrm{C}_{22}$ & 0.4 \\
\hline Hexacosanoic acid, heneicosyl ester & $\mathrm{C}_{26}: \mathrm{C}_{20}$ & 0.1 \\
\hline Octacosanoic acid, octadecyl ester & $\mathrm{C}_{28}: \mathrm{C}_{18}$ & 0.1 \\
\hline Triacontanoic acid, hexadecyl ester & $C_{30}: C_{16}$ & 0.5 \\
\hline Ester $C_{47}$ & & 3.1 \\
\hline Pentadecanoic acid, dotriacontyl ester & $\mathrm{C}_{15}: \mathrm{C}_{32}$ & 1.8 \\
\hline Hexadecanoic acid, hentriacontyl ester & $C_{16}: C_{31}$ & 0.9 \\
\hline Heptadecanoic acid, triacontyl ester & $C_{17}: C_{30}$ & 0.4 \\
\hline Ester $C_{48}$ & & 31.4 \\
\hline Tetradecanoic acid, tetratriacontyl ester & $\mathrm{C}_{14}: \mathrm{C}_{34}$ & 1.5 \\
\hline Hexadecanoic acid, dotriacontyl ester & $C_{16}: C_{32}$ & 24.7 \\
\hline Octadecanoic acid, triacontyl ester & $\mathrm{C}_{18}: \mathrm{C}_{30}$ & 3.5 \\
\hline Eicosanoic acid, octacosyl ester & $\mathrm{C}_{20}: \mathrm{C}_{28}$ & 0.7 \\
\hline Docosanoic acid, hexacosyl ester & $\mathrm{C}_{22}: \mathrm{C}_{26}$ & 0.2 \\
\hline Tetracosanoic acid, tetracosyl ester & $\mathrm{C}_{24}: \mathrm{C}_{24}$ & 0.2 \\
\hline Hexacosanoic acid, docosyl ester & $\mathrm{C}_{26}: \mathrm{C}_{22}$ & 0.3 \\
\hline Octacosanoic acid, heneicosyl ester & $\mathrm{C}_{28}: \mathrm{C}_{20}$ & 0.1 \\
\hline Triacontanoic acid, octadecyl ester & $\mathrm{C}_{30}: \mathrm{C}_{18}$ & 0.2 \\
\hline Ester $C_{49}$ & & 3.4 \\
\hline Pentadecanoic acid, tetratriacontyl ester & $\mathrm{C}_{15}: \mathrm{C}_{34}$ & 1.6 \\
\hline Hexadecanoic acid, tritriacontyl ester & $\mathrm{C}_{16}: \mathrm{C}_{33}$ & 1.1 \\
\hline Heptadecanoic acid, dotriacontyl ester & $C_{17}: C_{32}$ & 0.6 \\
\hline Octadecanoic acid, hentriacontyl ester & $C_{18}: C_{31}$ & 0.1 \\
\hline Ester $C_{50}$ & & 30.2 \\
\hline Tetradecanoic acid, hexatriacontanyl ester & $C_{14}: C_{36}$ & 0.3 \\
\hline Hexadecanoic acid, tetratriacontyl ester & $\mathrm{C}_{16}: \mathrm{C}_{34}$ & 18.8 \\
\hline Octadecanoic acid, dotriacontyl ester & $\mathrm{C}_{18}: \mathrm{C}_{32}$ & 5.7 \\
\hline Eicosanoic acid, triacontyl ester & $\mathrm{C}_{20}: \mathrm{C}_{30}$ & 3.5 \\
\hline Docosanoic acid, octacosyl ester & $\mathrm{C}_{22}: \mathrm{C}_{28}$ & 1.1 \\
\hline Tetracosanoic acid, hexacosyl ester & $\mathrm{C}_{24}: \mathrm{C}_{26}$ & 0.5 \\
\hline Hexacosanoic acid, tetracosyl ester & $\mathrm{C}_{26}: \mathrm{C}_{24}$ & 0.1 \\
\hline Octacosanoic acid, docosyl ester & $\mathrm{C}_{28}: \mathrm{C}_{22}$ & 0.2 \\
\hline Ester $C_{51}$ & & 2.0 \\
\hline Pentadecanoic acid, hexatriacontanyl ester & $\mathrm{C}_{15}: \mathrm{C}_{36}$ & 0.2 \\
\hline Hexadecanoic acid, pentatriacontanyl ester & $C_{16}: C_{35}$ & 0.2 \\
\hline Heptadecanoic acid, tetratriacontyl ester & $\mathrm{C}_{17}: \mathrm{C}_{34}$ & 0.5 \\
\hline Octadecanoic acid, tritriacontanyl ester & $\mathrm{C}_{18}: \mathrm{C}_{33}$ & 0.2 \\
\hline Nonadecanoic acid, dotriacontyl ester & $C_{19}: C_{32}$ & 0.2 \\
\hline Eicosanoic acid, hentriacontanyl ester & $\mathrm{C}_{20}: \mathrm{C}_{31}$ & 0.2 \\
\hline Heneicosanoic acid, triacontyl ester & $C_{21}: C_{30}$ & 0.5 \\
\hline Ester $C_{52}$ & & 24.4 \\
\hline Tetradecanoic acid, octatriacontanyl ester & $\mathrm{C}_{14}: \mathrm{C}_{38}$ & 0.4 \\
\hline Hexadecanoic acid, hexatriacontanyl ester & $\mathrm{C}_{16}: \mathrm{C}_{36}$ & 1.9 \\
\hline Octadecanoic acid, tetratriacontyl ester & $\mathrm{C}_{18}: \mathrm{C}_{34}$ & 4.2 \\
\hline Eicosanoic acid, dotriacontyl ester & $\mathrm{C}_{20}: \mathrm{C}_{32}$ & 9.0 \\
\hline Docosanoic acid, triacontyl ester & $\mathrm{C}_{22}: \mathrm{C}_{30}$ & 7.4 \\
\hline Tetracosanoic acid, octacosyl ester & $\mathrm{C}_{24}: \mathrm{C}_{28}$ & 0.8 \\
\hline Hexacosanoic acid, hexacosyl ester & $\mathrm{C}_{26}: \mathrm{C}_{26}$ & 0.3 \\
\hline
\end{tabular}

Table 2 (Continued)

\begin{tabular}{|c|c|c|}
\hline Individual esters & $\begin{array}{l}\text { Fatty acid:fatty } \\
\text { alcohol }\end{array}$ & Abundance \\
\hline Octacosanoic acid, tetracosyl ester & $\mathrm{C}_{28}: \mathrm{C}_{24}$ & 0.2 \\
\hline Triacontanoic acid, docosyl ester & $\mathrm{C}_{30}: \mathrm{C}_{22}$ & 0.2 \\
\hline Ester $C_{53}$ & & 1.7 \\
\hline Pentadecanoic acid, octatriacontanyl ester & $\mathrm{C}_{15}: \mathrm{C}_{38}$ & 0.1 \\
\hline Heptadecanoic acid, heptatriacontanyl ester & $\mathrm{C}_{17}: \mathrm{C}_{37}$ & 0.1 \\
\hline Heneicosanoic acid, dotriacontyl ester & $C_{21}: C_{32}$ & 1.0 \\
\hline Tricosanoic acid, triacontyl ester & $\mathrm{C}_{23}: \mathrm{C}_{30}$ & 0.5 \\
\hline Ester $C_{54}$ & & 26.5 \\
\hline Tetradecanoic acid, tetracontanyl ester & $\mathrm{C}_{14}: \mathrm{C}_{40}$ & 0.3 \\
\hline Hexadecanoic acid, octatriacontanyl ester & $\mathrm{C}_{16}: \mathrm{C}_{38}$ & 0.7 \\
\hline Octadecanoic acid, hexatriacontanyl ester & $C_{18}: C_{36}$ & 0.4 \\
\hline Eicosanoic acid, tetratriacontyl ester & $\mathrm{C}_{20}: \mathrm{C}_{34}$ & 4.6 \\
\hline Docosanoic acid, dotriacontyl ester & $\mathrm{C}_{22}: \mathrm{C}_{32}$ & 14.0 \\
\hline Tetracosanoic acid, triacontyl ester & $\mathrm{C}_{24}: \mathrm{C}_{30}$ & 5.9 \\
\hline Hexacosanoic acid, octacosyl ester & $\mathrm{C}_{26}: \mathrm{C}_{28}$ & 0.6 \\
\hline Ester $C_{55}$ & & 1.6 \\
\hline Heneicosanoic acid, tetratriacontanyl ester & $\mathrm{C}_{21}: \mathrm{C}_{34}$ & 0.4 \\
\hline Tricosanoic acid, dotriacontyl ester & $\mathrm{C}_{23}: \mathrm{C}_{32}$ & 0.8 \\
\hline Pentacosanoic acid, triacontyl ester & $\mathrm{C}_{25}: \mathrm{C}_{30}$ & 0.4 \\
\hline Ester $C_{56}$ & & 27.0 \\
\hline Hexadecanoic acid, tetracontanyl ester & $\mathrm{C}_{16}: \mathrm{C}_{40}$ & 0.5 \\
\hline Octadecanoic acid, octatriacontanyl ester & $C_{18}: C_{38}$ & 0.1 \\
\hline Eicosanoic acid, hexatriacontanyl ester & $\mathrm{C}_{20}: \mathrm{C}_{36}$ & 0.8 \\
\hline Docosanoic acid, tetratriacontyl ester & $\mathrm{C}_{22}: \mathrm{C}_{34}$ & 5.9 \\
\hline Tetracosanoic acid, dotriacontyl ester & $\mathrm{C}_{24}: \mathrm{C}_{32}$ & 15.8 \\
\hline Hexacosanoic acid, triacontyl ester & $\mathrm{C}_{26}: \mathrm{C}_{30}$ & 3.5 \\
\hline Octacosanoic acid, octacosyl ester & $\mathrm{C}_{28}: \mathrm{C}_{28}$ & 0.4 \\
\hline Ester $C_{58}$ & & 10.7 \\
\hline Tetracosanoic acid, tetratriacontyl ester & $\mathrm{C}_{24}: \mathrm{C}_{34}$ & 3.9 \\
\hline Hexacosanoic acid, dotriacontyl ester & $\mathrm{C}_{26}: \mathrm{C}_{32}$ & 6.8 \\
\hline
\end{tabular}

dotriacontanol $\left(\mathrm{C}_{32}\right)$ followed by tetratriacontanol $\left(\mathrm{C}_{34}\right)$ and triacontanol $\left(\mathrm{C}_{30}\right)$. Therefore, the predominant ester wax found among the jute lipophilic extracts was $\mathrm{C}_{48}(31.4 \mathrm{mg} / \mathrm{kg})$, which is mostly constituted by hexadecanoic acid $\left(\mathrm{C}_{16}\right)$ esterified to dotriacontanol $\left(C_{32}\right)$ (structure I in Fig. 3), followed by ester wax $C_{50}(30.2 \mathrm{mg} / \mathrm{kg})$, mostly constituted by hexadecanoic acid $\left(\mathrm{C}_{16}\right)$ esterified to tetratriacontanol $\left(\mathrm{C}_{34}\right)$, ester wax $\mathrm{C}_{56}(27.0 \mathrm{mg} / \mathrm{kg})$, mostly constituted by tetracosanoic acid $\left(C_{24}\right)$ esterified to dotriacontanol $\left(C_{32}\right)$, and by ester wax $C_{54}(26.5 \mathrm{mg} / \mathrm{kg})$, mostly constituted by docosanoic acid $\left(C_{22}\right)$ esterified to dotriacontanol $\left(C_{32}\right)$, as detailed in Table 2 .

Free fatty acids were the second most important class of lipophilic compounds identified in jute extracts $(130.2 \mathrm{mg} / \mathrm{kg})$, ranging from tetradecanoic $\left(\mathrm{C}_{14}\right)$ to tetratriacontanoic $\left(\mathrm{C}_{34}\right)$ acids, with a strong even-over-odd carbon atom predominance. Hexadecanoic (palmitic, III) and 9-octadecenoic (oleic, IV) acids were the most abundant, followed by octadecanoic (stearic, $\mathrm{C}_{18}$ ) and docosanoic $\left(\mathrm{C}_{22}\right)$ acids. Relatively high amounts of $\alpha$-hydroxyfatty acids ( $102.8 \mathrm{mg} / \mathrm{kg}$ ), ranging from $\mathrm{C}_{23}$ to $\mathrm{C}_{25}$ with $\mathrm{C}_{24}(\mathrm{~V})$ as the most abundant, and $\omega$-hydroxyfatty acids $\left(34.5 \mathrm{mg} / \mathrm{kg}\right.$ ) ranging from $\mathrm{C}_{22}$ to $\mathrm{C}_{24}(\mathrm{VI})$, the latest being the most abundant, were also identified. Series of $\alpha$-hydroxyfatty acids have been reported previously in both bast (i.e. flax, hemp, kenaf) and leaf (i.e. sisal, abaca, curaua) fibers (Gutiérrez and del Río, 2003a; Gutiérrez et al., 2004, 2006, 2008; del Río and Gutiérrez, 2006; Marques et al., 2007). However, $\omega$-hydroxyfatty acids have only been detected in leaf fibers (del Río and Gutiérrez, 2006; Gutiérrez et al., 2008; Marques et al., 2007), and this is the first report of the presence of these compounds in a bast fiber.

Series of $n$-fatty alcohols were present in the jute extracts in important amounts $(127.0 \mathrm{mg} / \mathrm{kg})$, ranging from $C_{16}$ to $C_{40}$ and with the presence of exclusively the even carbon atom numbered homologues. Dotriacontanol $\left(\mathrm{C}_{32}, \mathrm{VII}\right)$ was the most abundant homologue. Interestingly, the distribution of the series of free 
fatty alcohols parallels the distribution of the series of esterified fatty alcohols in the long-chain ester waxes, as also observed in the ester wax series present in other bast fibers such as flax, hemp or kenaf (Gutiérrez and del Río, 2003a,b; Gutiérrez et al., $2004,2006)$. A series of $n$-alkanes was also identified among the extracts of jute fibers $(48.5 \mathrm{mg} / \mathrm{kg})$ ranging from heptacosane $\left(C_{27}\right)$ to pentatriacontane $\left(C_{35}\right)$ with a strong odd-over-even carbon atom number predominance, tritriacontane $\left(C_{33}\right.$, II) being the most predominant. Finally, other aliphatic series present in smaller amounts are monoglycerides $(7.5 \mathrm{mg} / \mathrm{kg}$ ) and diglycerides $(13.5 \mathrm{mg} / \mathrm{kg})$, although triglycerides could not be found in jute extracts.

Sterols were also present in significant amounts $(43.4 \mathrm{mg} / \mathrm{kg})$ among the lipophilic extracts of jute fibers. Sitosterol (XI) was the most abundant among the free sterols, followed by stigmasterol (X) and campesterol (IX), with minor amounts of stigmastanol, 7-oxocampesterol and 7-oxositosterol. Steryl glycosides, such as campesteryl, stigmasteryl and sitosteryl 3 $\beta$-D-glucopyranosides (XII) were also identified although in minor amounts $(8.4 \mathrm{mg} / \mathrm{kg})$, the latter being the most predominant. The identification of steryl glycosides was accomplished (after BSTFA derivatization of the lipid extract) by comparison with the mass spectra and relative retention times of authentic standards (Gutiérrez and del Río, 2001).

Steroid hydrocarbons (ergosta-3,5,7-triene, XIII, stigmastatetraene, stigmasta-3,5,7-triene and stigmasta-3,5-diene) and steroid ketones (stigmasta-3,5-dien-7-one, XIV and stigmast-4-en-3-one, $\mathrm{XV}$ ) were also present. Several triterpenoid ketones were also identified, the most abundant being isomultiflorenone (D:C friedoolean-8-en-3-one) with minor amounts of bauerenone (D:C friedours-7-en-3-one) and $\beta$-amyrenone. The identification of the bauerenone and $\beta$-amyrenone was accomplished after SPE fractionation due to their low abundance and coelution with other major lipids. The mass spectra of the triterpenoid ketones present in jute fiber extracts (shown in Fig. 6) are similar to those reported in the literature (Budzikiewicz et al., 1963; Talapatra et al., 1968).

Finally, two compounds (peaks 8 and 9 in Figs. 1 and 2), with similar and characteristic mass spectra (Fig. 7), were also detected in important amounts among the jute lipophilic extracts. These compounds coelute very closely and were concentrated in the SPE $B$ fraction, where alcohols and sterols concentrate, indicating the possible presence of hydroxyl groups in their structure. The mass spectra of both compounds are characterized by a base peak at $\mathrm{m} / \mathrm{z} 143$, which is indicative of the presence of a hydroxypropyltetrahydrofuran side-chain (Fig. 7c), and are similar to the mass spectrum of the epoxy-dammarane triterpene capsugenin, a triterpenoid with a hydroxypropyltetrahydrofuran side-chain (Fig. 7d), previously identified in the extracts of jute leaves (Hasan et al., 1984; Quader and Ahmed, 1987; Quader et al., 1990). The molecular weight of these compounds could not be determined despite they were subjected to different derivatizations, although the fragments at $m / z 444$ and $m / z 442$ seem to correspond to a loss of water $[\mathrm{M}-18]^{+}$. The mass spectrum reported for capsugenin is very similar to the mass spectra of unknown compounds 8 and 9, with the same base peak at $m / z 143$ and a similar fragmentation profile. Therefore, these unknown compounds 8 and 9 seem to be structurally related to capsugenin.

We have reported the detailed chemical composition of the lipophilic extractives present in jute fibers. The knowledge of the chemical composition of lipophilic components of jute fiber will assist to predict and control the eventual pitch problems that may occur during pulping and bleaching and to establish appropriate methods and strategies for their control. In general terms, the lipids present in jute fibers can be classified into two principal groups, namely fatty acids (including $\alpha$ - and $\omega$-hydroxyfatty acids) and neutral components, including wax esters, long-chain $n$-fatty alcohols, alkanes, and steroids and triterpenoids. The differ-
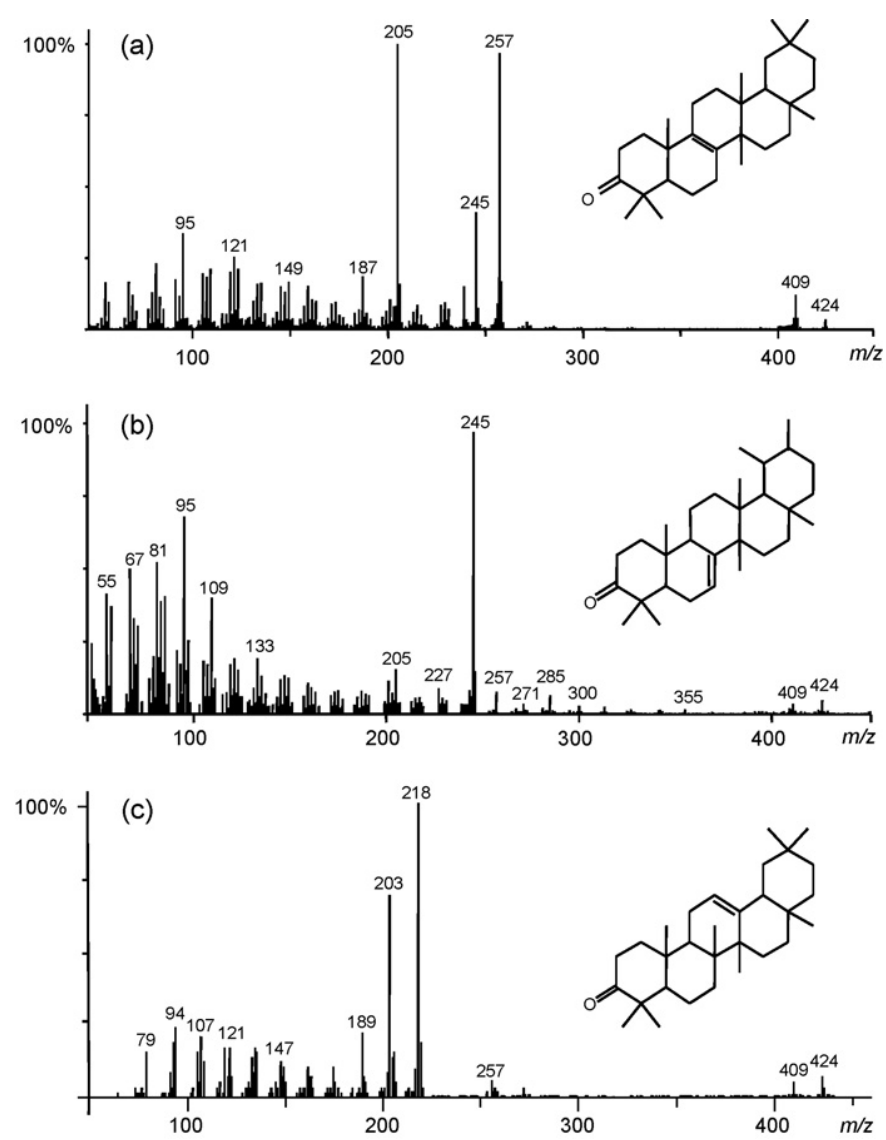

Fig. 6. Mass spectra and chemical structures of triterpenoids ketones identified among jute lipophilic extractives. (a) Isomultiflorenone; (b) bauerenone; and (c) $\beta$-amyrenone.

ent lipid classes have different behavior during cooking. The wax esters, which are the most abundant lipophilic compounds in jute fibers, are hydrolyzed during alkaline cooking and the fatty acids are dissolved. At sufficiently high $\mathrm{pH}$ (as in alkaline pulping), the acids dissociate and form fatty acid soaps and can thus dissolve in water to quite a high extent. On the other hand, alkanes, fatty alcohols, sterols and triterpenols, steroid hydrocarbons and ketones, and steryl glycosides do not form soluble soaps under the alkaline pulping conditions and therefore survive cooking and can be found intact in the pulp. These compounds have a very low solubility in water and are difficult to remove, and therefore can be at the origin of pitch deposition. The low amounts of these neutral compounds in jute fibers, and particularly the low abundances of free and conjugated sterols, which have a high propensity to form pitch deposits (del Río et al., 1998, 2000; Gutiérrez and del Río, 2001) would point to a low pitch deposition tendency of the lipophilics from jute fibers. On the other hand, fatty acid soaps are effective solubilizing agents facilitating the removal from pulp of sparingly soluble neutral substances. The ratio of saponifiables-to-unsaponifiables has been suggested to be a better index for predicting pitch problems than the total amount of lipids (Back and Allen, 2000). In fact, the higher abundances of unsaponifiable compounds (neutrals) with respect to the saponifiable ones are the main cause for pitch problems during pulping of some woods, such as aspen or eucalypt (Chen et al., 1995; del Río et al., 1998, 2000). In jute fibers the content of free fatty acids (including $\alpha$ - and $\omega$-hydroxyfatty acids) is high (around 33\% of total lipids), and therefore the fatty acid soaps formed during the cooking may possess sufficient micellar-forming properties to carry the less polar compounds into solution. 

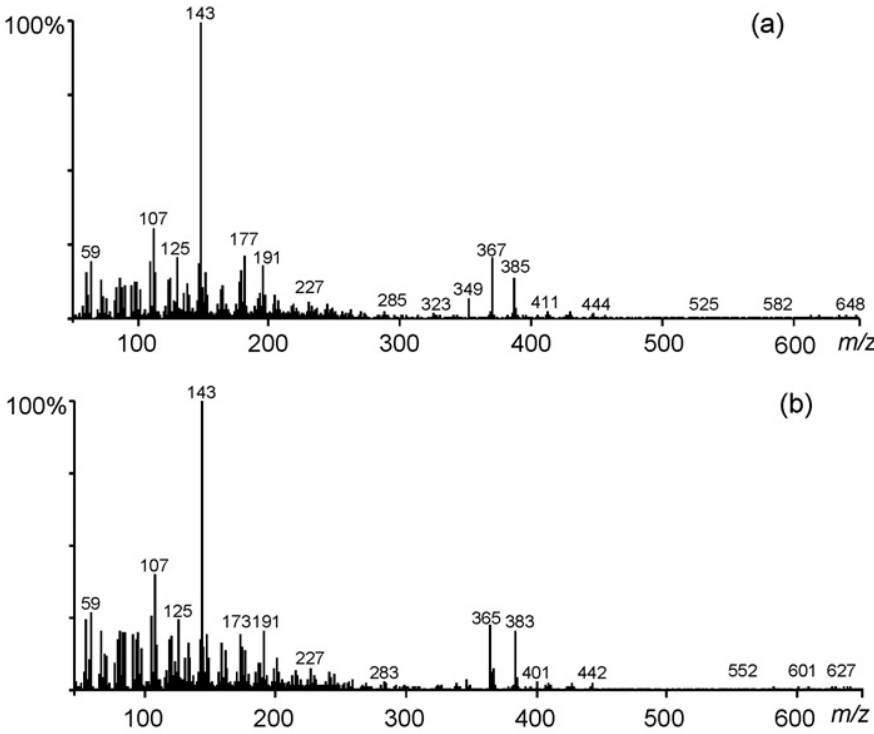

(c)

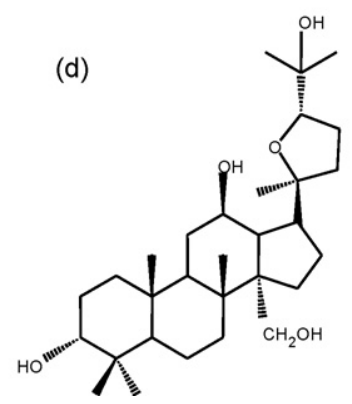

Fig. 7. Mass spectra of two unknown compounds present in jute (C. capsularis) fiber extracts. (a) Mass spectrum of unknown compound 8; (b) mass spectrum of unknown compound 9; (c) structure of the mass fragment at $\mathrm{m} / \mathrm{z} 143$; (d) structure of capsugenin (20,24-epoxy-3,12,25,30-tetrahydroxydammarane).

\section{Acknowledgements}

This study has been funded by the Spanish projects AGL200501748, AGL2008-00709 and BIO2007-28719-E, and the EU BIORENEW Project (NMP2-CT-2006-026456). GM thanks the Spanish Ministry of Education for a FPI fellowship. We also thank J.M. Gras and G. Artal (CELESA, Spain) for providing the jute fibers.

\section{References}

Akhtaruzzaman, A.F.M., Shafi, M., 1995. Pulping of jute. Tappi J. 78, 106-112.

Ali, M., Sreekrishnan, T.R., 2001. Aquatic toxicity from pulp and paper mill effluents: a review. Adv. Environ. Res. 5, 175-196.

Back, E.L., Allen, L.H., 2000. Pitch Control Wood Resin and Deresination. Tappi Press, Atlanta, GA.

Bergelin, E., Holmbom, B., 2003. Deresination of birch kraft pulp in bleaching. J. Pulp Paper Sci. 29, 29-34.

Bergelin, E., Moller, R., Holmbom, B., 2005. Analysis of pitch and deposit samples in kraft pulp production. Pap. Puu-Pap. Tim. 87, 399-403.

Budzikiewicz, H., Wilson, J.M., Djerassi, C., 1963. Mass spectrometry in structura and stereochemical problem XXXII. Pentacyclic triterpenes. J. Am. Chem. Soc. $85,3688-3699$

Chen, T., Wang, Z., Zhou, Y., Breuil, C., Aschim, O.K., Yee, E., Nadeau, L., 1995. Using solid-phase extraction to assess why aspen causes more pitch problems than softwoods in kraft pulping. Tappi J. 78, 143-149.

Coelho, D., Marques, G., Gutiérrez, A., Silvestre, A.R.D., del Río, J.C., 2007. Chemical characterization of the lipophilic fraction of Giant reed (Arundo donax) fibres used for pulp and paper manufacturing. Ind. Crops Prod. 26, 229-236.
Christianson-Heiska, I.L., Haavisto, T. Paranko, J., Bergelin, E., Isomaa, B., 2008. Effects of the wood extractives dehydroabietic acid and betulinol on reproductive physiology of zebrafish (Danio rerio)-a two-generation study. Aquat. Toxic 86, 388-396.

del Río, J.C., Gutiérrez, A., González-Vila, F.C., Martín, F., Romero, J., 1998. Characterization of organic deposits produced in kraft pulping of Eucalyptus globulus wood. J. Chromatogr. A 823, 457-465.

del Río, J.C., Romero, J., Gutiérrez, A., 2000. Analysis of pitch deposits produced in kraft pulp mills using a totally chlorine free bleaching sequence. J. Chromatogr. A 874, 235-245.

del Río, J.C., Gutiérrez, A., 2006. Chemical composition of abaca (Musa textilis) leaf fibers used for manufacturing of high quality paper pulps. J. Agric. Food Chem. $54,4600-4610$.

Freire, C.S.R., Silvestre, A.J.D., Pascoal Neto, C., 2005. Lipophilic extractives in Eucalyptus globulus kraft pulps. Behaviour during ECF bleaching. J. Wood Chem. Technol. 25, 67-80.

Freire, C.S.R., Silvestre, A.J.D., Pascoal Neto, C., Evtuguin, D.V., 2006. Effect of oxygen, ozone and hydrogen peroxide bleaching stages on the contents and composition of lipophilic extractives of Eucalyptus globulus kraft pulps. Biores. Technol. 97, 420-428.

Gutiérrez, A., del Río, J.C., González-Vila, F.J., Martín, F., 1998. Analysis of lipophilic extractives from wood and pitch deposits by solid-phase extraction and gas chromatography. J. Chromatogr. A 823, 449-455.

Gutiérrez, A., del Río, J.C., 2001. Gas chromatography/mass spectrometry demonstration of steryl glycosides in eucalypt wood, kraft pulp and process liquids. Rapid Commun. Mass Spectrom. 15, 2515-2520.

Gutiérrez, A., Romero, J., del Río, J.C., 2001a. Lipophilic extractives from Eucalyptus globulus pulp during kraft cooking followed by TCF and ECF bleaching. Holzforschung 55, 260-264.

Gutiérrez, A., Romero, J., del Río, J.C., 2001b. Lipophilic extractives in process waters during manufacturing of totally chlorine free kraft pulp from eucalypt wood. Chemosphere 44, 1237-1242.

Gutiérrez, A., del Río, J.C., 2003a. Lipids from flax fibers and their fate in alkaline pulping. J. Agric. Food Chem. 51, 4965-4971.

Gutiérrez, A., del Río, J.C., 2003b. Lipids from flax fibers and their fate in alkaline pulping (addition/correction). J. Agric. Food Chem. 51, 6911-6914.

Gutiérrez, A., Rodríguez, I.M., del Río, J.C., 2004. Chemical characterization of lignin and lipid fractions in kenaf bast fibers used for manufacturing high-quality papers. J. Agric. Food Chem. 52, 4764-4773.

Gutiérrez, A., del Río, J.C., 2005. Chemical characterization of pitch deposits produced in the manufacturing of high-quality paper pulps from hemp fibers. Biores. Technol. 96, 1445-1450.

Gutiérrez, A., Rodríguez, I.M., del Río, J.C., 2006. Chemical characterization of lignin and lipid fractions in industrial hemp bast fibers used for manufacturing highquality paper pulps. J. Agric. Food Chem. 54, 2138-2144.

Gutiérrez, A., Rodríguez, M.I., del Río, J.C., 2008. Chemical composition of lipophilic extractives from sisal (Agave sisalana) fibers. Ind. Crops Prod. 28, 81-87.

Hasan, C.M., Isla, A., Ahmed, M.-D., Waterman, P.G., 1984. Capsugenin, a dammarane triterpene from Corchorus capsularis. Phytochemistry 23, 2583-2588.

Hillis, W.E., Sumimoto, M., 1989. Effect of extractives on pulping. In: Rowe, J.W. (Ed.), Natural Products of Woody Plants II. Springer-Verlag, Berlin, pp. 880920.

Jahan, M.S. 2001. Evaluation of additive in soda pulping of jute. Tappi J. 84, 1-11.

Jahan, M.S., Al-Maruf, A., Quaiyyum, M.A., 2007. Comparative studies of pulping of jute fiber, jute cutting and jute caddis. Bangladesh J. Sci. Ind. Res. 42, 425434.

Jahan, M.S., Kanna, G.H., Mun, S.P., Chowdhury, D.A.N., 2008. Variations in chemical characteristics and pulpability within jute plant(Corchorus capsularis). Ind. Crops Prod. 28, 199-205.

Marques, G., Gutiérrez, A., del Río, J.C., 2007. Chemical characterization of lignin and lipophilic fractions from leaf fibers of curaua (Ananas erectifolius). J. Agric. Food Chem. 55, 1327-1336.

Moldovan, Z., Jover, E., Bayona, J.M., 2002. Systematic characterisation of long-chain aliphatic esters of wool wax by gas chromatography-electron impact ionisation mass spectrometry. J. Chromatogr. A 952, 193-204

Quader, M.A., Ahmed, M.-D., 1987. Capsugenin 30-O- $\beta$-diglucopyranoside: a new glycoside from the leaves of Corchorus capsularis. J. Nat. Prod. 50, 479-481.

Quader, M.A., Gray, A.I., Waterman, P.G., 1990. Capsugenin-25 30-O- $\beta$ diglucopyranoside: a new glycoside from the leaves of Corchorus capsularis. J Nat. Prod. 53, 527-530.

Sharkey Jr., A.G., Shultz, J.L., Friedel, R.A., 1959. Mass spectra of esters. Formation of rearrangement ions. Anal. Chem. 31, 87-94.

Silvestre, A.J.D., Pereira, C.C.L., Pascoal Neto, C., Evtuguin, D.V., Duarte, A.C., Cavaleiro, J.A.S., Furtado, F.P., 1999. Chemical composition of pitch deposits from ECF Eucalyptus globulus bleached kraft pulp mill: Its relationship with wood extractives and additives in process streams. Appita J. 52, 375-382.

Talapatra, S.K., Sengupta, S., Talapatra, B., 1968. A pentacyclic triterpene alcohol from Evodia fraxinipolia Hook F. Tetrahedron Lett. 57, 5963-5968. 